\title{
Original Result or Finding
}

National Cancer Institute

\section{Source}

National Cancer Institute. Original Result or Finding. NCI Thesaurus. Code C117221.

The outcome of the test or finding as originally received or collected. 